\title{
Pengaruh Pemberian Pupuk Organik Cair Nasa Dan Pupuk Kompos Terhadap Pertumbuhan Tanaman Kenaf ( Hibiscus cannabinus L)
}

\section{Effect Of Giving Nasa Liquid Organic Fertilizer And Composite Fertilizer To Kenaf Plant (Hibiscus cannabinus L) Growth}

\author{
Hairin Juanda ${ }^{1}$, Tutik Nugrahini ${ }^{2}$, Mahdalena ${ }^{2}$ \\ 1 Alumni Program Studi Agroteknologi, Fakultas Pertanian, Universitas Widya Gama Mahakam \\ ${ }^{2}$ Tenaga Pendidik Program Studi Agroteknologi, Fakultas Pertanian, Universitas Widya Gama Mahakam \\ Jl. KH. Wahid Hasyim, Sempaja, Samarinda, Kalimantan Timur \\ e-mail: haririnjuanda@gmail.com, tutiknugrahini@uwgm.ac.id, mahdalena@uwgm.ac.id
}

Diterima : 10 Mei 2018 Disetujui : 1 Juni 2018

\begin{abstract}
Effect of NASA Liquid Organic Fertilizer and Compost Fertilizer on Kenaf Plant Growth (Hibiscus cannabinus L). This study aims to determine the effect of NASA POC, compost fertilizer and the interaction of NASA POC and compost fertilizer on kenaf plants. This research was carried out at East Borneo Samarinda Indonesia. with a time of \pm 4 months, starting from June to September 2016. The design of the study uses factorial completely randomized design (CRD) consisting of 2 treatments and 4 replications. The treatment consists of 2 factors. The first factor is the administration of NASA POC consisting of 4 levels, namely: j0: Control (without treatment), j1: POC with a concentration of $10 \mathrm{ml} /$ liter of water, j2: POC with a concentration of $15 \mathrm{ml} /$ liter of water, j3: POC with a concentration of $20 \mathrm{ml} /$ liter of water. The second factor is Compost fertilizer consisting of 4 levels, namely: $k 0$ : Without the provision of Compost Fertilizer, k1: Composting 500 gram / polybag, k2: Composting Fertilizer 700 grams / polybag, k3: Composting 800 grams / polybag. From the analysis of variance showed that the effect of giving NASA POC (J), compost $(K)$ and the interaction of NASA POC and compost $(J K)$ did not affect the parameters of plant height $30 \mathrm{DAP}, 60 \mathrm{DAP}$ and $90 \mathrm{DAP}$, stem diameter $30 \mathrm{DAP}, 60 \mathrm{DAP}$ and $90 \mathrm{DAP}$, number of leaves 30 DAP, 60 DAP and 90 DAP, leaf area 30 DAP, 60 DAP and 90 DAP.
\end{abstract}

Keywords: Organic fertilizer, compost, kenaf

\section{PENDAHULUAN}

Kenaf (Hibiscus cannabinus L.) merupakan tanaman penghasil serat, selain untuk bahan baku kemasan produk-produk perkebunan, dari serat kenaf dapat dihasilkan berbagai produk penganeragaman (diversifikasi), seperti : kertas, pelapis dinding, interior mobil, geotekstil, soil safer, fiber drain, particle board, dan reinforcement plastic. Sedangkan daunnya mengandung protein kasar $24 \%$ yang sangat baik digunakan untuk pakan ternak unggas, ikan, pupuk. (Sastrosupadi dan A. Nurheru, 2006). Tanaman kenaf merupakan tanaman semusim dengan tipe pertumbuhan berbentuk tegak. Termasuk dalam tanaman hari pendek dan akan cepat berbunga bila panjang penyinaran matahari kurang dari 12 jam. Pada keadaan normal, pertumbuhan optimal kenaf berkisar pada umur 60- 90 hari dan biasa mencapai tinggi $4 \mathrm{~m}$ untuk tanaman yang tumbuh subur, namun tergantung dari varietas, kesuburan tanah, serta teknik budidaya. Kenaf dapat tumbuh hampir pada semua tipe tanah, tetapi tanah yang ideal untuk kenaf yaitu tanah lempung berpasir atau lempung liat berpasir dengan drainase yang baik. Tanaman kenaf agak tahan kekeringan, namun karena seluruh bagian vegetatifnya (batang) harus dipanen pada umur 3,5 - 4 bulan, maka ketersediaan air selama pertumbuhan harus cukup. Kebutuhan air untuk kenaf sebesar $600 \mathrm{~mm}$ selama empat bulan kisaran $\mathrm{pH}$ cukup luas, yaitu dari 4,5 - 6,5 sehingga kenaf dapat tumbuh baik di tanah yang agak masam (Sastrosupadi dan A. Nurheru, 2006).

Tanaman kenaf termasuk komoditas ramah lingkungan, karena mudah terdegradasi dan selama pertumbuhannya dapat menangkap carbon dioksida $(\mathrm{CO} 2)$ di udara sehingga dapat mengurangi pencemaran udara, keuntungan bagi masyarakat meningkatkan perekonomian masyarakat atau para petani. Tanaman atau tumbuhan sama halnya dengan manusia, butuh makan minum. Jika tidak mendapatkan makan dan minum tanaman akan tumbuh dengan tidak baik bahkan bisa layu dan mati. Untuk itu tanaman perlu diberikan makanan berupa pupuk. Begitu juga dengan tanaman kenaf sangat memerlukaan air dan pupuk untuk mendapatkan serat yang baik dan tumbuh dengan sempurna. Anonim (2014).

Pupuk organik cair NASA adalah salah satu pupuk cair yang jika digunakan pada waktu dan konsentrasi yang tepat dapat mengaktifkan penyerapan unsur hara oleh tanaman, dan juga 
dengan diimbangi perawatan dan pemupukan yang memadai dapat meningkatkan pertumbuan dan produksi hasil minimal sepuluh (10) persen jika dibanding dengan yang tidak disemprot dengan pupuk organik cair NASA.

Pupuk kompos merupakan alternativ yang tepat, karena selain harganya murah dan mudah didapat, juga merupakan pupuk lengkap karena mengandung semua unsur hara yang diperlukan untuk hidup dan tumbuhnya tanaman.

Berdasarkan uraian diatas, maka dianggap perlu melakukan penelitian tentang Pengaruh Pemberian Pupuk Organik Cair Nasa dan Pupuk Kompos Terhadap Pertumbuhan Tanaman Kenaf ( Hibicus cannabinus L ). Sebagai salah satu data dan informasi dalam budidaya tanaman kenaf dengan tujuan penelitian ini untuk mengetahui pengaruh pemberian, mengetahui pengaruh pemberian pupuk kompos pada tanaman kenaf dan mengetahui pengaruh interaksi pemberian POC NASA dan pupuk Kompos pada tanaman kenaf.

\section{BAHAN DAN METODE}

Tempat dilakukan penelitian di Kelurahan Gunung Panjang, Samarinda Seberang, Kalimantan Timur Kegiatan ini di lakukan selama \pm 4 bulan, terhitung mulai dari bulan Juni sampai dengan bulan September tahun 2016. Dari persiapan, pelaksanaan dan penyusunan laporan. Bahan yang digunakan dalam penelitian ini yaitu: benih tanaman kenaf, polybag, pupuk organik cair NASA dan Pupuk Kompos, tanah yang digunakan adalah tanah topsoil dari jenis podsolik merah dan kuning, pasir, sekam bakar, serta insektisida badik dan fungisida carino. Penelitian menggunakan Rancangan Acak Lengkap (RAL) faktorial yang terdiri dari 2 perlakuan dan 4 ulangan. Faktor pertama adalah POC NASA $(J)$ yang terdiri dari 4 taraf yaitu : $\mathrm{j}_{0}$ : Kontrol (Tanpa perlakuan), $\mathrm{j}_{1}$ : POC dengan konsentrasi $10 \mathrm{ml} /$ liter air, $\mathrm{j}_{2}$ : POC dengan konsentrasi $15 \mathrm{ml} / \mathrm{liter}$ air dan $\mathrm{j}_{3}$ : POC dengan konsentrasi $20 \mathrm{ml} /$ liter air. Faktor kedua adalah (K) (Pupuk Kompos) yang terdiri dari 4 taraf yaitu : $\mathrm{k}_{0}$ : Tanpa pemberian Pupuk Kompos, $\mathrm{k}_{1}$ : Pemberian Pupuk Kompos 500 gram/bedeng, $\mathrm{k}_{2}$ : Pemberian Pupuk Kompos 700 gram/bedeng dan $\mathrm{k}_{3}$ : Pemberian Pupuk Kompos 800 gram/bedeng. Prosedur penelitian meliputi : persemaian, persiapan media tanam, penanaman benih ke bedengan, aplikasi pemupukan, pemeliharaan tanaman (penyiraman, penyiangan, pengendalian hama dan penyakit), pengambilan (tinggi tanaman, diameter batang, jumlah daun, luas daun umur 30 hst, 60 hst dan 90 hst) dan Pengolahan Data menggunakan sidik ragam, apabila terdapat pengaruh pada sidik ragam maka dilakukan Uji lanjutan dengan menggunakan Beda Nyata Terkecil (BNT) pada taraf 5\% untuk membandingkan dua rata-rata perlakuan.

\section{HASIL DAN PEMBAHASAN}

\section{Pengaruh POC NASA}

Hasil analisis sidik ragam menunjukkan bahwa pemberian pupuk cair NASA (J) tidak berpengaruh nyata terhadap parameter tinggi tanaman 30 HST, 60 HST dan 90 HST, diameter batang $30 \mathrm{HST}$, $60 \mathrm{HST}$ dan $90 \mathrm{HST}$, jumlah daun 30 HST, 60 HST dan 90 HST, luas daun 30 HST, 60 HST dan 90 HST. Diduga bahwa kandungan N, P, dan K pada POC NASA yang rendah sehingga tidak berpengaruh terhadap pertumbuhan tanaman, hal ini sesuai dengan pendapat Nukuhaly (2012), dengan penyediaan $\mathrm{N}$ yang rendah pada fase generatif akan mempercepat penuaan daun sehingga dapat menghambat proses fotosintesis, begitu juga dengan kandungan $\mathrm{P}$ dan $\mathrm{K}$ rendah dapat mengurangi hasil tanaman. Menurut Anonim (2006), bahwa kandungan yang terdapat pada POC NASA : $\mathrm{N} \quad 0,06 \%, \mathrm{P}_{2} \mathrm{O}_{5} ; 0,01 \%$, dan $\mathrm{K}_{2} \mathrm{O} ; 0,11 \%$. Sedangkan menurut Nurtika (2009), bahwa pupuk tunggal dengan konsentrasi yang dibutuhkan untuk tanaman kenaf $\mathrm{N} ; 1,5 \%, \mathrm{P}_{2} \mathrm{O}_{5} ; 1,5 \%$, dan $\mathrm{K}_{2} \mathrm{O} ; 1,5 \%$ menghasilkan petumbuhan vegetatif dan generatif yang baik serta dalam proses metabolisme sel, fotosintesis dan respirasi sel sehingga dapat meningkatkan pertumbuhan pada tanaman kenaf. Dari kedua pendapat diatas sangat jelas perlakuan yang diberikan pada penelitian tanaman kenaf ini belum memenuhi standar aplikasi pupuk. Menurut Dwidjoseputro (1991), bahwa tanaman akan tumbuh subur dan memberikan hasil yang baik jika unsur hara yang dibutuhkannya tersedia dalam jumlah cukup dan seimbang Ditambahkan Anonim (2012), bahwa pemupukan melalui daun dapat mengalami kegagalan apabila konsentrasi larutan pupuk yang diberikan tidak sesuai, sehingga akan mengakibatkan efektivitas pupuk menjadi berkurang dan tidak terserapnya unsur hara yang terkandung pada larutan pupuk juga diduga karena setelah penyiraman larutan pupuk terjadi hujan sehingga unsur hara yang terkandung di dalam larutan pupuk terjadi pencucian, sehingga ikut larut bersama air hujan. Ditambahkan pula oleh Gardner, Pearce dan Mitchell (1991), bahwa pola pertumbuhan tanaman bervariasi, jangka waktu mungkin dari beberapa hari sampai bertahun - tahun tergantung pada tanaman atau organ tanamannya. 


\section{Pengaruh Pupuk Kompos}

Hasil sidik ragam menunjukkan bahwa pemberian pupuk Kompos (K) tidak berpengaruh nyata terhadap parameter tinggi tanaman 30 HST, 60 HST dan 90 HST, diameter batang $30 \mathrm{HST}$, $60 \mathrm{HST}$ dan $90 \mathrm{HST}$, jumlah daun 30 HST, 60 HST dan 90 HST, luas daun 30 HST, 60 HST dan 90 HST. Menurut Jones (2008), curah hujan terlalu tinggi bahkan terlalu rendah juga bisa menjadi penyebab rendahnya pertumbuhan pada tanaman, dengan curah hujan yang sangat rendah menyebabkan tanaman akan stres dan akan mengganggu pertumbuhan. Tanaman kenaf membutuhkan air yang banyak namun tidak dalam jumlah yang berlebihan. akar tanaman kenaf tidak akan berfungsi dengan baik dalam kondisi tergenang (anaerobik) sehingga menyebabkan penyerapan unsur hara terhambat. Ditambahkan Lingga dan Marsono (2005), dengan pemberian pupuk kompos kurang dari dosis yang optimal yang disarankan maka tidak akan memberikan pengaruh terbaik terhadap pertumbuhan pada tanaman.

\section{Pengaruh Interaksi Perlakuan}

Hasil analisis sidik ragam menunjukkan bahwa interaksi pemberian pupuk organik cair NASA dan pemberian pupuk Kompos (JxK) tidak berpengaruh nyata terhadap parameter tinggi tanaman 30 HST, 60 HST dan 90 HST, diameter batang 30 HST, 60 HST dan 90 HST, jumlah daun 30 HST, 60 HST dan 90 HST, luas daun $30 \mathrm{HST}, 60 \mathrm{HST}$ dan $90 \mathrm{HST}$. Hal ini diduga karena perlakuan konsentrasi POC NASA dan Kompos terhadap tanaman kenaf tidak terdapat hubungan yang saling mempengaruhi, sehingga masing-masing berpengaruh secara terpisah satu sama lainnya. Hal ini sesuai pendapat Steel dan Torrie (1991), bahwa bila pengaruh interaksi berbeda tidak nyata, maka disimpulkan bahwa diantara faktorfaktor perlakuan tersebut bertindak bebas. Ditambahakan Hanafiah (2014), bahwa apabila tidak ada interaksi, berarti pengaruh suatu faktor sama untuk semua taraf faktor lainnya dan sama dengan pengaruh utamanya. Sesuai dengan pernyataan tersebut, maka dapat disimpulkan bahwa kedudukan dari kedua faktor adalah sama-sama mendukung pertumbuhan tanaman, tetapi tidak saling mendukung bila salah satu faktor menutupi faktor lainnya. Untuk memperoleh efisiensi yang tinggi dari suatu pemupukan. Perlu diperhatikan beberapa faktor yang ikut menentukan efisiensi penggunaan pupuk yaitu : sifat dan ciri tanah, sifat dan kebutuhan tanaman, pola pertanian, jenis pupuk dan sifatnya, dosis pupuk, waktu pemupukan, metode atau cara pemupukan.

\section{KESIMPULAN}

1. Pengaruh pemberian POC NASA (J) tidak berpengaruh pada parameter tinggi tanaman 30 HST, 60 HST dan 90 HST, diameter batang 30 HST, 60 HST dan 90 HST, jumlah daun 30 HST, 60 HST dan 90 HST, luas daun 30 HST, 60 HST dan 90 HST.

2. Perlakuan pupuk kompos (K) tidak berpengaruh pada parameter tinggi tanaman 30 HST, 60 HST dan 90 HST, diameter batang 30 HST, 60 HST dan 90 HST, jumlah daun $30 \mathrm{HST}, 60 \mathrm{HST}$ dan $90 \mathrm{HST}$, luas daun 30 HST, 60 HST dan 90 HST. I

3. Interaksi pemberian POC NASA dan pupuk kompos (JK) tidak berpengaruh pada parameter tinggi tanaman $30 \mathrm{HST}, 60 \mathrm{HST}$ dan 90 HST, diameter batang 30 HST, 60 HST dan 90 HST, jumlah daun 30 HST, 60 HST dan 90 HST, luas daun $30 \mathrm{HST}, 60$ HST dan 90 HST.

\section{DAFTAR PUSTAKA}

Anonim, 2006. Buletin Penggunaan Pupuk Organik Cair NASA. Natural Nusantara, Yogyakarta.

Anonim. 2014. Buku Pintar Budidaya Tanaman Kenaf. Kanisus, Jakarta.

Anonim, 2012. "Mengenal Kompos Fermentasi Bokasi", Trubus, Vol. V, No. 2, Rajawali Jakarta. $195 \mathrm{hlm}$.

Dwidjoseputro, 1991. Mengenal Lebih Dekat Pupuk Organik Cair, Aplikasi dan Manfaatnya. Agromedia pustaka. Jakarta.

Hanafiah.K. 2014. Rancangan Percobaan Teori dan Aplikasi. Fakultas Pertanian Universitas Sriwijaya Palembang.

Hartati, S., Sujindro,US. Budi, 1990. Pengaruh Saat Panen Dan Letak Buah Pada Batang Terhadap Viabilitas Benih Kenaf Varietas HC 48. Balai Penelitian Tanaman Tembakau Dan Serat. Malang.

Iksan. 1990. Pengaruh Waktu Pemangkasan Dan Jarak Tanam Terhadap Pertumbuhan Dan Hasil Biji Kenaf Varietas Hc 48. Balai Malang.

Indriyani 2000. Membuat Kompos Secara Kilat. Penebar Swadaya, Jakarta. 
Jones, 2008. Pembudidayaan Secara Komersial. Penebar Swadaya, Jakarta. $123 \mathrm{hlm}$.

Lingga, P dan Marsono, 2005. Petunjuk Penggunaan Pupuk, Penebar Swadaya, Jakarta. $163 \mathrm{hlm}$.

Makmur.2004. Pengantar Pemuliaan Tanaman. Rineka Cipta.Jakarta

Mayadewi, N. N. A. 2007. Pengaruh Jenis Pupuk Kandang dan Jarak Tanam terhadap Pertumbuhan Gulma dan Hasil Jagung Manis. Jurusan Budidaya Pertanian.Jurnal Bidang Ilmu Pertanian.Agritrop.Vol. 26.No. 4 (2007).

Nugroho. 2000. Rumus-Rumus Statistik, Serta Penerapan. Raja Presindo Preseda. Jakarta.

Nukuhaly, 2012. Pupuk Organik Cair dan Padat, Pembuatan dan Aplikasi. Swadaya. Jakarta.

Nurtika. 2009. Pupuk Dan Cara Pemupukan. Bhineka Cipta, Jakarta.

Pambayon, Ratna. 2008. Pengaruh Jarak Tanam Terhadap Produksi Sayuran Indigeneos. Http// www blogs.go.id.bogor. IPB. 12 September 2012.

Putra, Gede, dan Efendi. 2010. Jarak Tanam dan Dosis Pupuk Kandang Ayam Terhadap Pertumbuhan dan Ukuran Biji Jagung Manis dilahan Kering yang Beriklim Basah.
http://repository.ipb.ac.id/.../E11hsu.pdf. Bali. 12 september 2012.

Sastrosupadi, danA.Nurheru, A. 2006. Budidaya Kenaf. Kenaf Monofografi. Balai Penelitian Pertanian Tembakau dan Serat. Balittas Malang.

Setyo Budi. 2006. Biologi Tanaman Kenaf Dalam Kenaf Buku 1 Belibangtan. Balittas. Malang.

Subhan. 1989. Pengaruh Jarak Tanam Dan Pemupukan Fospat Terhadap Pertumbuhan dan Hasil Kacang Jogo (Phasealus vulgaris. L). Bull. Penel. Horti. Vol. VIII. No. 2. Lembang. 12 hal.

Sumantri, B. 1991. Prinsip dan Prosedur Statistik. Gramedia Pustaka Utama. Jakarta.

Wibowo, S. 2009. Budidaya Bawang. Penebar Swadaya. 106 hal.Jogyakarta.

Winarto. 2006. Proposal Pengolahan Kenaf Menjadi Serat Dalam Kenaf Buku 2 Balibangtan. Balittas. Malang.

Yeti Heryatidan A. Syaffari K. 2005. Pengaruh Lebar Jalur Bersih Terhadap Pertumbuhan Jenis Meranti Merah Penghasil Tengkawang (S. stenopteradanS. mecistopteryx) di Hutan Penelitian Haurbentes, Bogor.Jurnal Penelitian Hutan dan Konservasi Alam. Vol. II. No. 2. Hal 149-156. 2005. 